International Journal of Instruction e-ISSN: 1308-1470 • www.e-iji.net

Article submission code: 20200109113205

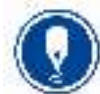

January $2021 \bullet$ Vol.14, No.1

p-ISSN: 1694-609X

pp. 761-778

Received: 09/01/2020

Revision: 27/07/2020
Accepted: 19/08/2020

OnlineFirst:15/11/2020

\title{
Task-Based Assessment in Using Other-Initiated Repair Strategies of the Pre-Service EFL Teachers
}

\section{Madar Aleksius}

Doctorate Student, Faculty of Letters, Universitas Negeri Malang, Indonesia; UNIKA Widya Mandira Kupang, Indonesia, alex_madar2000@yahoo.com

\section{Utami Widiati}

Prof., Faculty of Letters, Universitas Negeri Malang, Indonesia, utami.widiati.fs@um.ac.id

\section{Suharmanto}

Dr., Faculty of Letters, Universitas Negeri Malang, Indonesia, harmantoruslan@yahoo.com

Johannes Ananto Prayogo

Asst. Prof., Faculty of Letters, Universitas Negeri Malang, Indonesia johannes.ananto.fs@um.ac.id

The English teachers' ability to communicate does not only mean to transmit information in a one-way manner but also to be able to negotiate meaning in order to avoid possible misunderstandings that may cause a communication breakdown. Other-initiated repair (OIR) strategies are the strategies that can be deployed to solve understanding problems that deal not only to linguistics aspect but also hearing problems, poor speech delivery, or overall misunderstanding of intended meaning by the speakers in interaction. This paper aimed at outlining the way the pre-service EFL teachers' ability in using the OIR Strategies is assessed by using task-based assessment. Theoretical and empirical arguments were provided to support the development of communicative tasks assessment consisting of the assessment instruments, procedures, validation, blue-print, and validation. The developed assessment was implemented to a group of EFL pre-service teachers in a teacher college of Widya Mandira Catholic University in Indonesia. The result showed that the students were able to employ a set of OIR strategies to address the understanding problem in the interaction with their peers. It is concluded that the communicative task assessment is an effective way to elicit the students' ability in using OIR Strategies in the interaction so it should be incorporated in the speaking instruction to enhance the students communicative competence.

Keywords: speaking, communicative task, task-based assessment, conversation, otherinitiated repair strategies

Citation: Aleksius, M., Widiati, U., Suharmanto. \& Prayogo, J. A. (2021). Task-Based Assessment in Using Other-Initiated Repair Strategies of the Pre-Service EFL Teachers. International Journal of Instruction, 14(1), 761-778. https://doi.org/10.29333/iji.2021.14146a 


\section{INTRODUCTION}

Speaking is very important for English teachers because it is through this skill that they will conduct all their business as teachers in the classroom. We cannot imagine what the teachers will do in the classroom if he/she does not have adequate speaking skills in communicating with the students or with other fellow-teachers. In communicating with the students, teachers should be able to make himself/herself understandable by the students, and at the same time, he/she should understand the students' talk.

Given the importance of speaking for English teachers, the pre-service ELT education programs set up as one of the goals of their programs to impart learners the ability to use English effectively and accurately in communication. In the Indonesian ELT education program, this goal has been explicitly specified in its national curriculum which states that the graduates of the ELT program should master the linguistic theoretical concepts and general spoken and written communication strategies in general/mundane, academic and workplace contexts at an intermediate level. To respond to the curriculum requirement, the program incorporates the teaching of speaking into several subjects, namely Speaking for everyday Communication, Speaking for Group Activities, and Speaking for Formal Setting. These subjects are taught to the students when they are in semester 2, semester 3, and semester 4, respectively. The ultimate goal is that after semester four, their speaking skill has achieved the intermediate level, as required by the curriculum. However, since its implementation, there has been no systematic attempt to assess the students' competence in speaking, especially their ability to use communication strategies in real-life communication settings.

In order to reveal the students' communicative competence, we designed an assessment tool by using the communicative task as prompt to elicit students' communicative competence/ability. Communicative competence covers several components, namely grammatical competence, socio-cultural competence, discourse competence and strategic competence (Canale \& Swain, 1980). This notion of communicative competence was extended by including interactional competence as a vital component in conjunction with other components of communicative competence (Celce-Murcia, 2007). This paper will focus on strategic competence (Canale \& Swain, 1980) or interactional competence (Celce-Murcia, 2007) as an aspect of speaking ability.

For EFL students, interactional competence would be hard to achieve without explicit instruction because it is not something that can be mastered automatically but needs to be learned and practiced. It commonly happens in a conversation that the participants would find unknown words or structures, or what the speaker is saying is not clear. The presence of such problems will result in an understanding problem between the interlocutors. In order to solve the understanding problem in conversation, the interlocutors should find ways or strategies so that conversation will not cease. The interlocutors may use the phrases like "pardon?", "what?" or a more colloquial one like "Eh?" Another possible way to do is by repeating the unclear part and adding question words "what", such as in "He what"? or "He agreed what?"(Nation \& Newton, 2009). These strategies are call negotiation of meaning devices or in Conversation Analysis 
theory they are called other-initiated repair strategies (Wong \& Waring, 2010). These strategies are taught and learned for the sake of fluency in interaction.

\section{LITERATURE REVIEW}

\section{Other-Initiated Repair}

In this assessment, the focus is on how the Other-Initiated Repair (OIR) Strategies are employed by the students as evidence of the interactional ability. OIR is one of the aspects of analysis in the Conversation Analysis (CA) study. CA itself is "the study of the social organization of natural conversation that concerned with how meaning and pragmatic functions are communicated in both mundane and institutional talk" (Richards \& Schimth, 2002). This definition shows that CA studies not only mundane talk but also interactions in a formal and institutional setting such, in the courtroom, in classroom, or interactions between the doctors and the patients. There are three concepts studied in CA, namely (a) the sequential organization of talk; (b) turn-taking; and (c) the ways how people identify and repair communicative problems (Richards \& Schimth, 2002) and overall structuring practices, i.e. the ways of organizing a conversation as a whole as in openings and closings (Wong \& Waring, 2010).

In the fields of SLA and ELT, the relevance of CA has been articulated by several authors (for examples, (Macbeth, 2004) (Huth, 2011; Kasper \& Wagner, 2014; Markee, 2000; Seedhouse, 2004, 2005a; Wong \& Waring, 2010) ). Some of those authors even wrote a book-length account on the application of CA's theoretical and methodological principles in studying the interactions that occur in ESL/EFL classroom settings (Markee, 2000; Seedhouse, 2004; Wong \& Waring, 2010). Meanwhile, Huth (2011) asserts the application of CA in a language classroom could help the teachers explicate the interaction pattern of language learning tasks produced by the learners. One particular aspect of CA that has strong relevance in language teaching and learning is the repair organization because it specifically addresses the description and analysis of understanding problems which commonly happen in ESL/EFL learners' interactions (He \& Young, 1998). In addition, it is also vital for the language teachers to understand how breakdowns in communication and misunderstandings are repaired, as repair in the L2 classroom tends to carry a heavier load than in other settings (Seedhouse, 2005b).

Repair is defined as the treatment of trouble occurring in interactive language use (Seedhouse, 2005b) such as in speaking, hearing, or understanding of talk (Wong \& Waring, 2010). The mechanism of repair in conversation can be distinguished based on who performs the repair acts. According to Liddicoat (Liddicoat, 2007) repair can be divided into two types: (a) self-initiated repair, in which the repair act is performed by the speaker of the trouble source himself/herself, and (b) other-initiated repair, in which the repair act is done by other participant(s) in the conversation. This paper focuses on the other-initiated repair, the teaching of which would benefit the improvement of EFL learners' speaking proficiency.

The sequence of other-initiated repair starts from the presence of a trouble source in a speaker's turn. This trouble will prompt the employment of repair initiation by the other speaker, which is then followed by repair outcome produced by the trouble source 
speaker (Wagner \& Gardner, 2004). Wong \& Waring define trouble source as word, phrase, or utterance treated as problematic by the participants; repair initiation as the practice of signaling or targeting a trouble source; and repair outcome as the solution of the trouble source or abandonment of the problem. The sources of trouble in interaction take different kinds of forms, such as grammatical errors, the imperfection of speech delivery, clarifications, or mishearing that may impede mutual understanding between parties in the interaction. In order to overcome the understanding problems due to the presence of such trouble sources, the conversational participants need to use certain strategies, called other-initiated repair strategies, so that the conversation will not breakdown or cease.

\section{Task-based Assessment}

The OIR strategies do not come into use in an isolated sentence but they are enacted during the course of interaction. One way to reveal how they are used in interaction is by eliciting the students' speech production in a conversational interaction by using communicative tasks. The use of tasks in language teaching has been practiced for a long time as a part of Communicative Language Teaching (CLT). Communicative task has been claimed to have a great potential to engage learners in conversational interaction that allows them to creatively construct their own utterances. Ellis (2009) describes a communicative task as a meaning-focused activity, which involves a need to convey information and enables learners to use the linguistic means available to them in order to work towards a clearly defined outcome. According to Mackey \& Gass (2005), communicative tasks promote negotiation of meaning and communicative interaction.

In this paper, the communicative task is used not as a teaching method but as an assessment technique to elicit the use of OIR strategies as one of the traits of interaction competence. Meanwhile Coplin \& Gaysen (2006) defines assessment tasks as a tool to elicit language and strategies that are believed to underlie successful language performance. In addition, Gunadi (2016) adds that the communicative task is used to measure the test-takers' language performance that focuses not on the accurate use of language components but rather on success in meaning negotiation. It means that language accuracy does not become the main target of evaluation but the success in conveying the intended meaning albeit broken language. The strength of communicative task is also articulated by Garcia (2007) saying that communicative tasks are considered as the principal means by which learners can be provided opportunities to negotiate meaning and as appropriate tool both to assist language learning and the study the process of SLA.

There are some requirements to develop good communicative task assessment in order that it may function properly to measure the learners' ability in using the language for communication. The most important requirement is that the instrument should use "authentic materials, authentic tasks, and integratedness of language skills" (Gunadi, 2016) with the following requirements:

- Tasks in the test should resemble as far as possible to the ones as would be found in real life in terms of communicative use of language; 
- The test items need to be contextualized;

- The test items should address the definite audience for a purposeful communicative intent to be conveyed

- Test instructions and scoring plans should ouch on effective communication of meaning rather than on grammatical accuracy.

- Language should be productively drawn off as a result of the test, rather than merely recognized.

Communicate tasks may consist of different types. Pica, Kanagy, \& Falodun (1993) provided a framework to classify tasks based on four characteristics: interactant relationship, interaction requirement, goal orientation, and outcome options. Based on these characteristics, communicative task types can be divided into a range of continuum from the ones that generate the most opportunities for interactants to engage in negotiation, to those that generate the least. On the basis of this characterization, task types comprise of the jigsaw, information-gap, problem-solving, decision-making, and opinion exchange. Garcia (2007), then, elaborated that the jigsaw task would generate the most opportunities for negotiation of meaning, because interactants hold different portions of the information needed to complete the task and, therefore, must give and request information as they work toward a convergent single goal. At the opposite end of the continuum, the opinion exchange task would generate the least opportunities for negotiation of meaning because each interactant has access to the same information, and there is no requirement for interactants to converge toward a single goal in order to complete the task. In this paper, we used problem-solving task type to assess the preservice EFL teachers in using OIR strategies as part of the speaking ability.

The studies that use communicative tasks as a way of eliciting speaking in general and the use of OIR strategies, in particular, have been conducted in different research settings. For example, Herrera Mosquera (2012) conducted a study in a foreign language class with low-level proficiency. The study found that task-based language assessment is not only possible but effective in tapping the students communicative and linguistics performance. Álvarez (2006) studied the effect of task types on the use of Lexical Innovation Strategies in Interlanguage Communication of undergraduate L2 English. The participants of the study have three levels of English proficiency (beginner, intermediate, and advanced) and they were asked to perform three different tasks which imposed different linguistic, communicative and cognitive demands, ranging from less naturalistic to more spontaneous and natural communication: picture description, storytelling, and interview (p. 207). It was found that more controlled and linguistically demanding tasks would facilitate the students to create new terms, while in lesscontrolled tasks, the students use other mechanisms such as reduction or avoidance strategies. The study concluded that task-type influenced the choice of and frequency of use of different strategy types.

Using the so-called "Table Conversation" task, Yasui (2010) studied the correlation between the employment of repair strategies and language proficiency in the English- 
Japanese conversation group. Conversation Table task is similar to free discussion task where participants talk for about two hours three times a week about their everyday experience or about their academic matters. The study investigated conversational repair as a corrective activity of troubles in conversation, during a native and non-native speaker interaction in an informal language learning setting. The analysis revealed that the non-native speakers orient toward their language proficiency or deficiency through their repair processes. While the advanced learner's language proficiency is displayed through his preference for self-repair, the beginning learner exhibits his limitation in language competence through his preference for other-repair. Therefore, the findings indicate that the non-native speaker's identity as advanced or beginning learners is made relevant on a moment-by-moment basis during the interaction. The study also showed how mutual understanding was accomplished by interactional participants through the use of repair sequences. In this case, the repair sequences do not only deal with linguistic errors but also various understanding problems in interaction.

Another study of NNS - NNS interaction was conducted by Buckwalter (2001) who explored the social and cognitive behavior of learners participating in second language speaking activities. There were six different types of tasks used in this study: personal interview, role play, sharing, discussion, and information gap. Buckwalter employed both qualitative and quantitative approaches in his study. The qualitative approach was used by seeing the repair act as a lens to examine the data. The quantitative approach was used to calculate and compare the occurrence of self- repair and self-initiated repair within groups of the subject. The finding shows that self-repairs and self-initiated repairs were found to be dominant in the lexicon and morphosyntactic level. This applies to all the tasks used in the study.

Some studies specifically focused on the use of certain types of tasks, such as the Jigsaw task in the studies by Yoshida (2018) and Kade, Degeng, \& Ali (2019). The studies found that jigsaw tasks increased the students' performance and understanding of concepts. The studies on the use of tasks in EFL settings are also found in some other research. Al Khateeb \& Alshahrani (2019) showed that telecollaborative task has the potential of heightening the students' linguistic, communicative and intercultural skills. Similarly, Azkarai \& Imaz Agirre (2016) and Ismail \& Samad (2014) found that task difference influenced the students' understanding of both the message and grammar of the language and that students should be aware of their repair practice in the interaction because it could enhance their language development.

It may be inferred from the review of the studies above that communicative tasks are effective techniques in studies that aim at eliciting the students speaking or interactional ability. They can be used for different language learning contexts with students of different proficiency levels, including in the EFL context where the students' proficiency levels vary greatly. Communicative tasks can also be used specifically to study the ability of pre-service EFL teachers in using other-initiated repair strategies in conversation as shown in the instrument developed for this paper. Therefore, the research question proposed to be answered in this paper is: "How does the developed 
communicative task to tap the pre-service EFL students' ability in using other-initiated repair in their conversations?"

\section{METHOD}

\section{Participants}

The instrument was implemented to the sixth-semester students of English Education Study Program of Widya Mandira Catholic university in Kupang, Indonesia. These students have passed all the speaking subjects in the previous semesters, namely Speaking for Everyday Communication, Speaking for Group Activities, and Speaking for Formal Setting. In addition, they have also passed all the English Grammar Subjects, namely Basic English Grammar, Complex English Grammar, and Advanced Complex English Grammar as well as the vocabulary subject. It may be assumed that these students have adequate knowledge of language components and speaking skills to perform a conversation in an authentic manner.

The total number of students is 73 . However, for the sake of convenience, 10 students are asked to perform the conversation. The implementation was conducted in May 2017 at one of the classrooms at the university. All the steps presented in the task procedure above were strictly followed and the students seem to have a good understanding of what and how to perform the task.

\section{Instruments}

The communicative task used for this assessment is called "One Day in London" which was adapted from the book "Keep Talking: Communicative Fluency Activities for Language Teaching" by Klippel, (1984). "One Day in London" is an example of a problem-solving task type where students have to discuss and find the solution to various types of problems. The problem in this task provides the situation which the students might perceivably have to face outside of the classroom. To perform the task successfully the students had to take part actively in the interaction to express their opinion or offer a solution to the problem.

The task worksheet for the students is as follows.

Description of the situation:

"You have to plan to spend a day in London with your partner. Both of you arrive at Heathrow airport at 9 a.m. and you have to be back at the airport at 9 p.m. There is a self-drive car which you may use. It has a full tank. You receive 100 dollars, but you have no other money. Decide what you would like to do. You should plan the day in such a way that you are happy with it."

\section{Instruction:}

1) Work in pairs. Discuss with your partner to find out what you would like to do and what would you not like to do.

2) Work out a timetable for the day. 
3) You have 10 minutes to finish the task.

4) Use English as much as possible.

5) Speak clearly to your partner so he/she can understand you.

6) When your partner says something that you don't understand, seek for clarification.

7) Your interaction is recorded, so please speak loud enough so that your voice can be captured by the recorder.

Good luck and thank you for your cooperation.

\section{The procedure of Data Elicitation}

The procedure for performing the task can be explained as follows.

Table 1

The procedure of task performance

\begin{tabular}{|c|c|c|c|}
\hline Steps & Teacher & Students & Purpose \\
\hline I & $\begin{array}{l}\text { Explains about the } \\
\text { activity }\end{array}$ & $\begin{array}{l}\text { Listen to the teacher's } \\
\text { explanation }\end{array}$ & $\begin{array}{l}\text { To introduce the students about } \\
\text { the purpose of the meeting }\end{array}$ \\
\hline II & Explains about the task & $\begin{array}{l}\text { Listen to the teacher's } \\
\text { explanation }\end{array}$ & $\begin{array}{l}\text { To make the students } \\
\text { understand the task }\end{array}$ \\
\hline III & $\begin{array}{l}\text { Distribute the task sheet } \\
\text { to all the students }\end{array}$ & & \\
\hline IV & $\begin{array}{l}\text { Asks the students to read } \\
\text { the task individually }\end{array}$ & Study the task sheet & $\begin{array}{l}\text { To make the students have a } \\
\text { solid understanding of the task } \\
\text { and what to do. }\end{array}$ \\
\hline V & $\begin{array}{l}\text { Gives chance to the } \\
\text { students to ask question }\end{array}$ & $\begin{array}{l}\text { Ask questions to the } \\
\text { teacher for things } \\
\text { unclear for them }\end{array}$ & $\begin{array}{l}\text { To clarify any unclear issues } \\
\text { regarding the task and how to } \\
\text { perform it. }\end{array}$ \\
\hline VI & $\begin{array}{l}\text { Put students in pairs to } \\
\text { perform the task }\end{array}$ & $\begin{array}{l}\text { Work in pair to } \\
\text { perform the task }\end{array}$ & To produce conversations \\
\hline VII & $\begin{array}{l}\text { Record the students' } \\
\text { interaction }\end{array}$ & $\begin{array}{l}\text { Perform the } \\
\text { conversations }\end{array}$ & $\begin{array}{l}\text { To be used to analyze the } \\
\text { students' use of OIR Strategies } \\
\text { using the prepared rubric }\end{array}$ \\
\hline VIII & Closes the activity & & \\
\hline
\end{tabular}

\section{Assessment Rubric}

The assessment of students' ability in using OIR Strategies does not involve the use of scoring. Therefore the appropriate assessment rubric that can be used is a tally sheet proposed by Fraenkel \& Wallen (2006) to record the frequency of the OIR strategies. The assessment rubric can be shown in Table 2 below. 
Table 2

Assessment rubric

\begin{tabular}{|c|c|c|c|c|c|c|c|c|c|c|}
\hline \multirow{3}{*}{ Student } & \multicolumn{8}{|c|}{ OIR Strategy Types } & \multirow{2}{*}{\multicolumn{2}{|c|}{ Total }} \\
\hline & \multicolumn{2}{|l|}{1} & \multicolumn{2}{|l|}{2} & \multicolumn{2}{|l|}{3} & \multicolumn{2}{|l|}{4} & & \\
\hline & Tally & $\mathrm{n}$ & tally & $\mathrm{N}$ & Tally & $\mathrm{N}$ & tally & $\mathrm{n}$ & $\mathrm{N}$ & $\%$ \\
\hline Student 1 & & & & & & & & & & \\
\hline Student 2 & & & & & & & & & & \\
\hline Student 3 & & & & & & & & & & \\
\hline Student 4 & & & & & & & & & & \\
\hline
\end{tabular}

\section{The Blue Print of OIR Strategies}

The categories used as the basis for the determination of types of OIR strategies that occurred in students' conversations were mainly based on the work proposed by Schegloff, Jefferson, \& Sacks (1977) and Wong \& Waring (2010). These categories were used as a guideline while the actual occurrence depends on whether or not the participants employed them in their conversations.

Table 3

OIR strategies blue print

\begin{tabular}{|c|c|c|}
\hline No & $\begin{array}{l}\text { Types of OIR } \\
\text { Strategies } \\
\end{array}$ & Definition \\
\hline 1. & $\begin{array}{l}\text { Open class OIR } \\
\text { strategy or } \\
\text { unspecified repair } \\
\text { strategy. }\end{array}$ & $\begin{array}{l}\text { This strategy is usually used with no specification of trouble source in } \\
\text { the turn prior to the OIR strategy, whether the problem is related to } \\
\text { hearing, misunderstanding of talk, or both. The repair initiation is } \\
\text { indicated by the use of Huh?, What? Pardon? I'm sorry? }\end{array}$ \\
\hline 2. & $\begin{array}{l}\text { WH-Interrogative } \\
\text { OIR }\end{array}$ & $\begin{array}{l}\text { This strategy involves the use of a single question word such as who, } \\
\text { where, when as repair initiation that specifies trouble source of prior } \\
\text { turn. }\end{array}$ \\
\hline 3. & $\begin{array}{l}\text { Partial repetition of } \\
\text { trouble- source }+ \\
\text { WH-interrogative } \\
\end{array}$ & $\begin{array}{l}\text { In this strategy, a question word is used together with the repetition of } \\
\text { the trouble source turn. }\end{array}$ \\
\hline 4. & $\begin{array}{l}\text { Partial repetition of } \\
\text { the trouble-source }\end{array}$ & $\begin{array}{l}\text { In this strategy, some parts of the trouble source turn are used again in } \\
\text { repair initiation, usually delivered in rising intonation to convey } \\
\text { uncertainty which serves to invite the speaker of the trouble-source to } \\
\text { complete the repair }\end{array}$ \\
\hline 5. & $\begin{array}{l}\text { You mean }+ \\
\text { understanding } \\
\text { check }\end{array}$ & $\begin{array}{l}\text { In this strategy, the repair initiation involves an understanding check } \\
\text { often preceded by You mean. It is done by targeting more specifically } \\
\text { the trouble in the previous speaker's turn. }\end{array}$ \\
\hline 6. & $\begin{array}{l}\text { Exposed Correction } \\
\text { Repair Strategy }\end{array}$ & $\begin{array}{l}\text { It refers to stopping the trajectory of talks to overtly address a trouble- } \\
\text { source }\end{array}$ \\
\hline 7. & $\begin{array}{l}\text { Request for } \\
\text { Repetition. }\end{array}$ & $\begin{array}{l}\text { In this strategy, the interlocutor who initiates the repair explicitly asks } \\
\text { the previous speaker to repeat his/her utterance that might cause a } \\
\text { problem in understanding }\end{array}$ \\
\hline & $\begin{array}{l}\text { Non-Verbal Repair } \\
\text { Strategy }\end{array}$ & $\begin{array}{l}\text { This strategy includes the use of gesture, bodily movement, gaze, } \\
\text { facial expression and silence to indicate that one is having a problem } \\
\text { in understanding the utterance of the previous speaker }\end{array}$ \\
\hline
\end{tabular}




\section{Instrument Validation}

In order to establish the validity, the instrument was validated by an expert lecturer who has extensive experience in teaching Assessment Development courses both at undergraduate and Master's levels. The validator assessed the instrument on the clarity and grammaticality of the task description, task procedures, and instruction for the students. The result of the validation showed that the expert provided "yes" to all the statements on the validation sheet.

\section{Recording and Transcription}

In order to facilitate the identification of OIR strategies occurrence, the students' conversations were video- and audio-recorded. The recorded conversations were, then, transcribed in order to help us in analyzing how the OIR strategies were performed by the students.

\section{FINDINGS}

\section{The occurrence of OIR Strategies in the students' task-based conversations}

Table 4 presents the results of the analysis of students' employment of OIR strategies in the conversations.

Table 4

Students' employment of OIR Strategies in conversations

\begin{tabular}{|c|c|c|c|c|c|c|c|c|c|c|c|}
\hline \multirow[t]{2}{*}{ Pair } & \multirow[t]{2}{*}{ Students } & \multicolumn{8}{|c|}{ OIR Types } & \multirow[t]{2}{*}{ Total } & \multirow[t]{2}{*}{$\%$} \\
\hline & & 1 & 2 & 3 & 4 & 5 & 6 & 7 & 8 & & \\
\hline \multirow[t]{2}{*}{ Pair 1 } & S1 & 1 & 0 & 0 & 3 & 2 & 0 & 0 & 0 & 6 & 11.11 \\
\hline & S2 & 0 & 0 & 0 & 4 & 0 & 0 & 0 & 0 & 4 & 7.4 \\
\hline \multirow[t]{2}{*}{ Pair 2} & S3 & 1 & 0 & 0 & 1 & 0 & 1 & 0 & 0 & 3 & 5.55 \\
\hline & S4 & 1 & 0 & 0 & 1 & 1 & 2 & 0 & 0 & 5 & 9.25 \\
\hline \multirow[t]{2}{*}{ Pair 3} & S5 & 4 & 0 & 0 & 2 & 0 & 0 & 1 & 0 & 7 & 12.96 \\
\hline & S6 & 2 & 0 & 0 & 1 & 0 & 1 & 0 & 0 & 4 & 7.4 \\
\hline \multirow[t]{2}{*}{ Pair 4} & S7 & 0 & 0 & 0 & 2 & 1 & 0 & 0 & 0 & 3 & 5.55 \\
\hline & S8 & 0 & 0 & 0 & 1 & 0 & 1 & 0 & 0 & 2 & 3.70 \\
\hline \multirow[t]{2}{*}{ Pair 5} & S9 & 1 & 0 & 0 & 0 & 1 & 0 & 0 & 0 & 2 & 3.70 \\
\hline & S10 & 0 & 0 & 0 & 8 & 5 & 5 & 0 & 0 & 18 & 33.33 \\
\hline Total & & & & & & & & & & 54 & 100 \\
\hline
\end{tabular}

Based on the data from table 5, it showed that all the students employed OIR strategies to address understanding problems in their conversations. Student 10 seemed to be the most prolific in the OIR production with a total frequency of 18 cases or $33.33 \%$ of the total cases, followed far behind by student 5 with 7 OIR $(12.96 \%)$. Student 1 produced $6(11.11 \%)$ OIR strategies in her conversation with student 2 . Students 2 and 6 produced the same number of OIR strategies, each with a frequency of 4 cases or $7.4 \%$. The rest of the students employed less than four OIR strategies. Two students (S8 and S9) produced the least OIR strategies in their conversations, both with only two cases respectively. 
The data on table 5 also depicts that not all the OIR types were employed by the students in their conversations. Table 6 below presents the types of OIR strategies that occurred in the pre-service EFL teachers' conversations.

Table 5

Distribution and frequency of OIR types

\begin{tabular}{llll}
\hline OIR Types & Total & $\%$ \\
\hline 1. & Open class OIR strategy or unspecified repair strategy & 10 & 18.51 \\
\hline 2. & WH-Interrogative OIR & 0 & 0 \\
\hline 3. & Partial repetition of trouble- source + WH-interrogative & 0 & 0 \\
\hline 4. & Partial repetition of the trouble-source & 23 & 42.59 \\
\hline 5. & You mean + understanding check & 10 & 18.51 \\
\hline 6. & Exposed Correction Repair Strategy & 10 & 18.51 \\
\hline 7. & Request for Repetition & 1 & 1.85 \\
\hline 8. & Non-Verbal Repair Strategy & 0 & 0 \\
\hline Total & 54 & 100 \\
\hline
\end{tabular}

As shown in table 6, a total of 54 OIR strategies occurred in students' conversation. However, not all types of OIR strategies were used by the students. Out of eight types of OIR strategies proposed by (Schegloff et al., 1977) and (Wong \& Waring, 2010), the students performed five strategies in their conversations. The highest OIR type was type 4 (partial repetition of the trouble-source OIR strategy) which yielded 23 (42.59) cases. The second-highest occurrence with 10 cases $(18.51 \%)$ were three OIR strategies, namely open class or unspecified repair strategy, You mean + understanding check, and exposed correction repair strategy. Request for repetition OIR strategies appeared only once or $1.85 \%$ of the total cases. The OIR strategies that did not occur in the students' conversations were (1) type 2-WH interrogative OIR; (2) type 3 - partial repetition of trouble source + WH interrogative; and (3) type 8 - nonverbal repair strategy.

\section{Qualitative analysis of OIR Strategies employment}

In order to illustrate how the OIR strategies are used in students' conversation, we provided some conversation excerpts for each type of OIR strategy, taken randomly from the 5 conversations produced by the students. All the names that appeared in the excerpts below are pseudo names. 
Excerpt 1: open class or unspecified OIR strategy

1. Lili : thank you so ah maybe ah:: do have other idea? Maybe do you want to::=

2. Charles : ah okay..

3. Lili : go to some other places

4. Charles : after we go in King Cross station uh: if we have enough time we go the Big Ben or in ah Bekingam palace

5. Lili : sorry?

6. Charles : ah Bekingham palace

7. Lili : but you=

8. Charles : I am sorry my pronunciation is not good=

9. Lili : oh yah=

10. Charles : because I am from Indonesia

Excerpt 1 demonstrates an example of the employment of open class OIR strategy with the question 'sorry? to indicate a hearing problem in the conversation. As seen in line 5, Lili seemed to have a problem in understanding Charles' turn in line 4 because she could not hear it well. Charles' utterance in line 4 contained an incorrect pronunciation of the phrase "Bekingam palace" which caused a misunderstanding problem for Lili. To resolve this misunderstanding, Lili employed the open class OIR strategy "sorry?" in line 5 and responded by Charles in line 6 by repeating the phrase "Bekingam palace". The repetition seemed to solve the understanding problem.

Excerpt 2: partial repetition of trouble-source OIR strategy

1 Yulius : yeah that's a good places for us to go there

2 Maris : Yes

3 Yulius : but ya:: it tooks like thirty minutes to go there

4 Maris : thirty minutes from here?

5 Yulius : yeah that's a good places for us to go there

6 Maris : Okay

In excerpt 2, the employment of partial repetition occurred in line 4 of Maris' turn when she said "thirty minutes from here?" which was a repetition of parts of Yulius' utterance in line 3. By using this strategy, Maris wanted to clarify that she had a proper understanding of Yulius message in line 3. Yulius responded it with a confirmation "yeah" in line 5, and it seemed that Maris'understanding problem was resolved. 
Excerpt 3: open class and you mean + understanding check

1 Angel : so:::: where place you want to visit again for::=

2 Eni : mmm I want to visit roller coster roller coster? (wrong pronunciation)

3 Angel : I am sorry?

4 Eni : ruler- roller coaster? (wrong pronunciation)

5 Angel : no. do you mean roller coaster?

6 Eni : RIGHT exactly roller coaster

7 Angel : okay we'll go there

8 Eni : okay we'll go there

There were two OIR strategies that occurred in excerpt 3, namely open class strategy in line 3 and you mean + understanding check in line 5. The employment of 'I am sorry?' as an open class OIR strategy by Angel probably because she could not understand Eni's utterance in line 4 because it contained incorrect pronunciation of the word "roller coaster". The understanding problem was attempted to be solved by Eni in line 4 by repeating her utterance but it seemed that Angel still not understand the utterance so she initiated an understanding check OIR strategy in line 5 by saying "do you mean roller coaster?" The understanding problem was resolved right away by Eni in line 6 by confirming that what she meant was actually a roller coaster".

\section{Excerpt 4: exposed correction OIR strategy}

1 Angel : Maybe we can eat our lunch there?

2 Eni : yes we can but uh: how many

3 Angel : how much

4 Eni : how much that we spend for our lunch

5 Angel : I don't know, we can go there and see

In line 3, Angel corrected Eni's incorrect use of "how many". Eni is talking about the money they would spend for lunch. Since "money" is an uncountable noun, "how much" is grammatically correct. Eni accepted Angel's correction by repeating it in her utterance in line 4.

Excerpt 5: request for repetition OIR strategy

1 Angel : so how about you. what you want to eat

2 Eni : uhm:: steak twenty five dollars, sandwhich (2) I want sandwhich

3 Angel : huh?

4 Eni : Sandwich 


$$
\begin{array}{llll}
5 & \text { Angel } & : & \text { one more time } \\
6 & \text { Eni } & : & \text { Sandwich } \\
7 & \text { Angel } & : & \text { Sandwich } \\
8 & \text { Eni } & : & \text { it's only twenty dollars } \\
9 & \text { Angel } & : & \text { Okay }
\end{array}
$$

It is very clearly seen in line 5 of Angel's turn that she is asking Eni to repeat her utterance at line 4 by using the phrase "one more time". This might be caused by Eni's unclear pronunciation of the word "sandwich" that created an understanding problem for Angel. Eni repeated the word in line 6, thus solving the problem for Angel.

\section{DISCUSSION AND CONCLUSION}

In this paper, we have outlined the way to assess the ability of the pre-service EFL teachers in using the OIR Strategies. We have argued, theoretically and empirically, that one effective way to assess such ability is by using communicative tasks. To verify the argument, a task-based assessment (TBA) was developed and implemented to a group of pre-service EFL teachers at a small private university in Kupang, Indonesia.

Based on the analysis of the occurrence of OIR strategies in the conversations produced by EFL students, it can be established that the employment of task-based assessment was effective in tapping the students' ability to enact OIR strategies in addressing the understanding problems. The finding is in line with Herrera Mosquera's (2012) study in foreign language classroom that task-based language assessment is not only possible but effective in eliciting the students' communicative and linguistics performance. The implementation of problem solving communicative task in the current study also shows similar result with the studies of Yoshida (2018) and Kade, Degeng, \& Ali (2019) that employed jigsaw task in investigating the students' speaking performance and comprehension of content materials.

In terms of the types of OIR strategies, however, the current study found it to be different from the ones proposed by Schegloff et al. (1977) and Wong \& Waring (2010). In combination, the two authors proposed eight types of OIR, namely Open class or unspecified, WH-Interrogative, Partial repetition of trouble- source + WHinterrogative, Repetition or Partial repetition of the trouble-source, candidate understanding, Correction Repair Strategy, Request for Repetition, and Non- Verbal Repair Strategy. In the current study, only 5 OIR types occurred in the students' conversations: Open class OIR strategy or unspecified repair strategy, Partial repetition of the trouble-source, You mean + understanding check, Exposed Correction Repair Strategy, and Request for Repetition.

Regardless of the variability in the employment of OIR strategies across the students and the types, the students managed to enact the OIR practice in their classroom conversations to address the understanding problems by the implementation of taskbased assessment. In this case, through their task-based conversations, the students 
collaboratively construct their language learning, making the teaching and learning process becomes the initiative of the learners themselves, and not only the responsibility of the teacher. Thus, using tasks could effectively assess the students' ability to address understanding problems which is part of their interactional competence (Celce-Murcia, 2007). In addition, the students' competence can also be enhanced by engaging them in an interaction with their teacher both face to face or using other modes of communications such as social media or mobile tools (Denizalp \& Ozdamli, 2019).

In conclusion, it can be asserted that the use of task-based assessment is effective in eliciting and measuring the pre-service EFL teachers' ability in using OIR Strategies in conversation and interaction. Regardless of their low-level proficiency in English levels, the EFL students managed to enact the OIR practice in their classroom conversations to address the understanding problems by employing various types of OIR strategies. By employing OIR strategies in solving understanding problems, students collaboratively construct their language learning process, making the teaching and learning process becomes the initiative of the learners themselves, and not only the responsibility of the teacher.

The current study provides language educators a better understanding of the process of assessing the EFL learners' ability in dealing with understanding problems in communication. By knowing how the EFL students address the understanding problem in classroom conversations, the teachers get more insights about how to develop speaking materials and lessons to help enhance the students' interactional ability. Therefore, it is a necessity for EFL educators to systematically prepare the teaching materials, design the speaking classes, and develop task-based assessment that incorporate these strategies so that the students' interactional ability to avoid communication breakdowns would develop gradually.

However, it should be noted that not all OIR strategies are employed in this task. There might be various reasons for the non-existence of those strategies, such as a limited number of participants and the use of only one type of task. It is suggested, then, that the future researchers use more task types to stimulate the students' performance in speaking, hence, increase the chance for them to employ more types of OIR strategies.

\section{ACKNOWLEDGMENT}

This study was partly supported by Yapenkar (the Arnoldus Catholic Education Foundation) to whom we owe our gratitude.

\section{REFERENCES}

Al Khateeb, A. A., \& Alshahrani, K. S. (2019). Investigating language-related tasks in EFL settings in light of tele-collaboration phenomenon and sociocultural theory. International Journal of Emerging Technologies in Learning, 14(3), 151-165. https://doi.org/10.3991/ijet.v14i03.9418

Álvarez, E. G. (2006). Task-effect on the use of lexical innovation strategies in interlanguage communication. In Investigating Tasks in Formal Language Learning. https://doi.org/10.21832/9781853599286-013 
Azkarai, A., \& Imaz Agirre, A. (2016). Negotiation of Meaning Strategies in Child EFL Mainstream and CLIL Settings. TESOL Quarterly. https://doi.org/10.1002/tesq.249

Canale, M., \& Swain, M. (1980). Theoretical bases of communicative approaches to second language teaching and testing. Applied Linguistics, 1(1), 1-47. https://doi.org/10.1093/applin/I.1.1

Celce-Murcia, M. (2007). Rethinking the role of communicatice competence in language teaching. In E. . Solerand \& M. . Safont-Jorda (Eds.), The intercultural language use and language learning (pp. 41-58). Dordrect: Springer.

Coplin, S., \& Gaysen, S. (2006). Developing and introducing task-based testing. In K. Van den Banden (Ed.), Task-based language education: from theory to practice (pp. 151-174). Cambridge: Cambridge University Press.

Denizalp, H., \& Ozdamli, F. (2019). Determination of Student Opinions on Usage of Social Media and Mobile Tools in Student-Teacher, Student-Student Communication. International Journal of Emerging Technologies in Learning, 14(22), 19-28. https://doi.org/https://doi.org/10.3991/ijet.v14i22.11745

Ellis, R. (2009). Task-based language teaching: sorting out the misunderstanding. International Journal of Applied Linguistics, 19(3), 221-246.

Fraenkel, J. R., \& Wallen, N. E. (2006). The Basic of Educational Research. In How to design and evaluate resaerch in education with PowerWeb.

Garcia, M. F. (2007). Tasks, negotiation, and L2 learning in a foreign language context. In M. D. G. P. Mayo (Ed.), Investigating tasks in formal language learning (pp. 69-90). Clevedon, Buffalo and Toronto: Mulltilingual Matters Ltd.

Gunadi, G. S. (2016). EFL learning assessment at schools: An introduction to its basic concepts and principles. Malang: Bintang Sejahtera.

He, A. W., \& Young, R. (1998). Language proficiency interviews: a discourse approach. In Talking and testing: discourse approaches to the assessment of oral proficiency (pp. 1-25). Amsterdam and Philadelphia: John Benjamins Publishing Company.

Herrera Mosquera, L. (2012). Using Tasks to Assess Spanish Language Learning. GIST Education and Learning Research Journal.

Huth, T. (2011). Conversation Analysis and Language Classroom Discourse. Language \& Linguistics Compass, 5(5), 297-309. https://doi.org/10.1111/j.1749818x.2011.00277.x

Ismail, L., \& Abd. Samad, A. (2014). Using Tasks and Repair Practices in the Malaysian L2 Classroom. Asia-Pacific Education Researcher. https://doi.org/10.1007/s40299-013-0124-7

Kade, A., Degeng, I. N. S., \& Ali, M. N. (2019). Effect of jigsaw strategy and learning style to conceptual understanding on senior high school students. International Journal 
of Emerging Technologies in Learning, 14(19), 14-15. https://doi.org/10.3991/ijet.v14i19.11592

Kasper, G., \& Wagner, J. (2014). Conversation analysis in applied linguistics. In Annual Review of Applied Linguistics (Vol. 34). https://doi.org/10.1017/S0267190514000014

Klippel, F. (1984). Keep talking : comunicative fluency activities for language teaching (p. 202). p. 202. Cambridge: Cambridge University Press.

Liddicoat, A. J. (2007). An Introduction to Conversation Analysis. London and New York: Continuum.

Macbeth, D. (2004). The Relevance of Repair for Classroom Correction. Language in Society, 33(5), 703-736. Retrieved from https://www.jstor.org/stable/4169386

Mackey, A., \& Gass, S. M. (2005). Second Language Research: Methodology and Design. Mahwah, New Jersey and London: Lawfrence Erlbaum Associates.

Markee, N. (2000). Conversation Analysis. Mahwah, New Jersey and London: Lawrence Erlbaum Associates.

Nation, I. S. P., \& Newton, J. (2009). Teaching ESL/EFL Listening and Speaking. In ESL Applied Linguistics Professional Series (Vol. 15). https://doi.org/10.1016/j.system.2009.11.002

Pica, T., Kanagy, R., \& Falodun, J. (1993). Choosing and Using Communication Tasks for Second Language Instruction. In G. Crookes \& S. M. Gass (Eds.), Tasks and Language Learning: Integrating Theory and Practice (pp. 9-34). Clevedon, Philadelphia and Adelaide: Mulltilingual Matters Ltd.

Richards, J. C., \& Schimth, R. (2002). Longman dictionary of Language teaching and Applied linguistics. London: Longman.

Schegloff, E. A., Jefferson, G., \& Sacks, H. (1977). The Preference for Self-Correction in the Organization of Repair in Conversation. Language, 53(2), 361. https://doi.org/10.2307/413107

Seedhouse, P. (2004). The Interactional Architecture of the Language Classroom: A Conversational Analysis Perspective. Malden, MA: Blackwell Publishing.

Seedhouse, P. (2005a). Conversation Analysis and language learning. Language Teaching, 38(4), 165-187. https://doi.org/10.1017/S0261444805003010

Seedhouse, P. (2005b). Conversation Analysis and language learning. Language Teaching. https://doi.org/10.1017/S0261444805003010

Wagner, J., \& Gardner, R. (2004). Introduction. In J. Wagner \& R. Gardner (Eds.), Second Language Conversations (pp. 4-17). London and New York: Continuum.

Wong, J., \& Waring, H. Z. (2010). Conversation Analysis and Second Language Pedagogy: A Guide for ESL/EFL Teachers. New York and London: Routledge. 
Yasui, E. (2010). Repair and Language Proficiency: Differences of Advanced and Beginning Language Learners in an English-Japanese Conversation Group. TPFLE Buckwalter, 14(1).

Yoshida, M. (2018). Communication Jigsaw: A teaching method that promotes scholarly communication. International Journal of Emerging Technologies in Learning, 13(10), 208-224. https://doi.org/10.3991/ijet.v13i10.8850 